\title{
Deuterium Exchange Between Arenes and Deuterated Solvents in the Absence of a Transition Metal: Synthesis of D-Labeled
} Fluoroarenes

\author{
Vanesa Salamanca and Ana C. Albéniz ${ }^{*[a]}$ \\ [a] Dr. V. Salamanca and Prof. Dr. A. C. Albéniz \\ IU CINQUIMA/Química Inorgánica. Universidad de Valladolid. 47071 Valladolid (Spain). \\ Universidad de Valladolid \\ 47071 Valladolid (Spain). \\ E-mail: albeniz@qi.uva.es \\ Supporting information for this article is given via a link at the end of the document.
}

\begin{abstract}
Fluoroarenes can be selectively deuterated by $H / D$ exchange with common deuterated solvents in the presence of a catalytic amount of an alkali metal carbonate or, for the less acidic arenes, stoichiometric quantities of potassium phosphate. This is a sustainable method that does not need transition metal catalysis or the multistep synthesis of a main-group organometallics. This exchange needs to be taken into account when using $H / D$ scrambling as a mechanistic probe in reactions involving fluoroarenes.
\end{abstract}

\section{Introduction}

Deuterated compounds have important applications in different areas of chemistry. ${ }^{[1]}$ Beyond the widespread use of these derivatives in NMR spectroscopy and MS, the substitution of $D$ for $\mathrm{H}$ in a molecule opens up new possibilities for reactivity control and the collection of mechanistic information. The higher strength of E-D bonds when compared to E-H bonds allows the application of deuterated derivatives in mechanistic studies by measuring kinetic isotope effects (KIE). ${ }^{[2]}$ This KIE can also be exploited to either enhance or minimize a specific reaction pathway and therefore increasing the selectivity of a reaction, ${ }^{[3,4]}$ or even to slow down the metabolism of a drug if it involves an $\mathrm{X}-\mathrm{H}(\mathrm{D})$ cleavage, ${ }^{[5]}$ therefore prolonging its pharmacological action. The use of deuterium as a flag is also very important and the analysis of the fate of deuterium in a specifically labeled deuterated molecule that undergoes a reaction can give extremely useful mechanistic information.

In the course of our mechanistic studies on palladium-catalyzed direct arylation reactions we needed to prepare deuterated fluoroarenes but the synthesis of these seemingly simple derivatives is not always straightforward. For this reason, we developed and describe here a convenient deuteration of fluoroarenes by $\mathrm{H}-\mathrm{D}$ exchange with a deuterated solvent that occurs in the absence of a transition metal (Scheme 1c). Besides their application for the synthesis of molecules with $F$ and $D$ atoms in a simple and sustainable way, these results show that caution should be applied in some mechanistic studies involving fluoroarene or heteroarene functionalizations. Thus, H/D scrambling may occur in a transition metal catalyzed arene coupling, for example, with no involvement of the metal and such an experiment would give no information regarding the role of the catalyst.

Several deuteration procedures for fluoroarenes can be found scattered in the literature. Although not very atom-economical, one laboratory procedure for the synthesis of deuterated fluoroarenes could be the protonolysis of organometallic derivatives with $\mathrm{D}_{2} \mathrm{O}$ (Scheme 1a) ${ }^{[6]}$ However, the stability of the common organolithium derivatives in the case of fluoroaryls is low, mainly due to LiF elimination to benzynes and subsequent evolution. ${ }^{[7]}$ This means that the synthesis of $\operatorname{LiAr}_{F}$ has to be done under strictly controlled conditions, ${ }^{[8]}$ and, when hydrolyzed, mixtures of compounds are often obtained. Recent advances on

a) From organometallic compounds

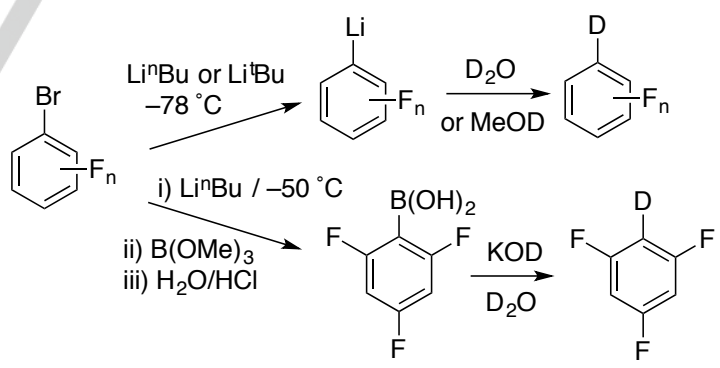

b) Transition metal catalysis<smiles>[2H]c1c(F)cccc1F</smiles>

c) This work

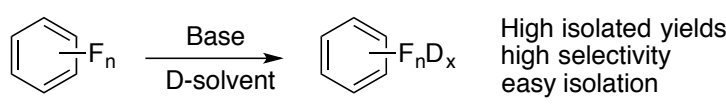

Base $=\mathrm{M}_{2} \mathrm{CO}_{3}, \mathrm{~K}_{3} \mathrm{PO}_{4}, \mathrm{NaOH}$

D-solvent $=\mathrm{D}_{2} \mathrm{O}$, acetone-d6, DMSO-d6

Scheme 1. Some deuteration methods for fluoroarenes. 
the generation of organometallic arylfluorides using a two-metal combination have increased the synthetic utility of these derivatives, but this does not contribute to the atom-efficiency or the reactions. ${ }^{[9]}$ The hydrolysis of fluoroaryl boronic acids with $\mathrm{D}_{2} \mathrm{O} / \mathrm{KOD}$ to give deuterated arenes has also been reported. ${ }^{[10]}$ Besides the distinct stability problems of active metal fluoroaryl derivatives, all these methods require the previous synthesis of organometallic compounds by metalation or halogen exchange in one or two synthetic steps, and lack the required atomeconomy to become a sustainable synthetic protocol (Scheme 1a). Electrophilic aromatic substitution under strong thermal conditions has been tried for the deuteration of fluoroarenes but it has only been achieved in the presence of electron donating groups in the ring (i.e. monofluorinated anilines). ${ }^{[11]}$ Transition metal catalysis has also been tested and Larrosa et al. used a silver salt in the presence of triphenylphosphine and $\mathrm{D}_{2} \mathrm{O}$ to deuterate a number of fluoroaryls in moderate yields (Scheme 1b). ${ }^{[12]}$ The role of silver in this exchange was also observed later by Sanford et al. for $\mathrm{C}_{6} \mathrm{~F}_{5} \mathrm{H} .{ }^{[13]}$ Photochemical conversion of $C-X(X=$ halogen $)$ to $C-D$ bonds with $\mathrm{D}_{2} \mathrm{O}$ catalyzed by porous CdSe nanosheets has been applied to several fluorosubstituted aryl halides. ${ }^{1} 14 \quad$ ] Some transition-metal catalyzed $\mathrm{C}-\mathrm{H}$ deuterations in the literature have reported an occasional example of a monofluorinated molecule in their scope. ${ }^{[1 c, 15]}$

The source of deuterated compounds is ideally $\mathrm{D}_{2} \mathrm{O}$. Nowadays, a large amount of deuterated derivatives are commercially available, many of them common organic solvents for their use in NMR spectroscopy. Acetone-d6 and DMSO-d6 are synthesized by exchange of the protic solvent with $D_{2} O$ in the presence of a base, and they are among the easiest prepared and least expensive solvents. ${ }^{[16]}$ These two deuterated solvents have been used in this work as a source for the mild and efficient deuteration of fluoroarenes and other arenes by deuterium exchange in the presence of an alkali metal base. This is a convenient way that does not require expensive, scarce or hazardous reagents or a multi-step chemical synthesis (Scheme 1c).

\section{Results and Discussion}

Our study started with the deuteration reaction of pentafluorobenzene. The synthesis of $\mathrm{C}_{6} \mathrm{~F}_{5} \mathrm{D}$ is based on the equilibrium shift of the reaction shown in Eq. 1 (calculated $\mathrm{K}_{\mathrm{eq}}=$ 0.98 at $363 \mathrm{~K}$ ) using an excess of the deuterated solvent as the deuterium source in the presence of a catalytic amount of base.

$$
\mathrm{C}_{6} \mathrm{~F}_{5} \mathrm{H}+\text { acetone-d } \frac{\mathrm{Cs}_{2} \mathrm{CO}_{3}}{\underset{90^{\circ} \mathrm{C}}{\rightleftharpoons}} \mathrm{C}_{6} \mathrm{~F}_{5} \mathrm{D}+\text { acetone-d5- } \mathrm{H}
$$

It is very easy to follow the reaction course by ${ }^{19} \mathrm{~F}$ NMR, since this nucleus shows a strong isotopic shift of the fluorine resonances. $\mathrm{C}_{6} \mathrm{~F}_{5} \mathrm{D}$ signals can be clearly distinguished from those of $\mathrm{C}_{6} \mathrm{~F}_{5} \mathrm{H}$ : about $0.3 \mathrm{ppm}$ shift for the $\mathrm{F}_{\text {ortho, and a reduction }}$ of the coupling constants $J_{F-D}$ when compared to $J_{F-H}\left(\gamma_{D} / \gamma_{H}=\right.$ 0.1535 ) that affects the multiplicity of the signals (see Figure 1 and the Supporting Information for other fluoroarenes).

As shown in Table 1 , just $3 \mathrm{~mol} \%$ of cesium carbonate is enough to obtain near a quantitative deuteration of pentafluorobenzene at $90{ }^{\circ} \mathrm{C}$ in $1 \mathrm{~h}$ (entry 2, Table 1). It is possible to lower the temperature to $50{ }^{\circ} \mathrm{C}$ but the reaction times

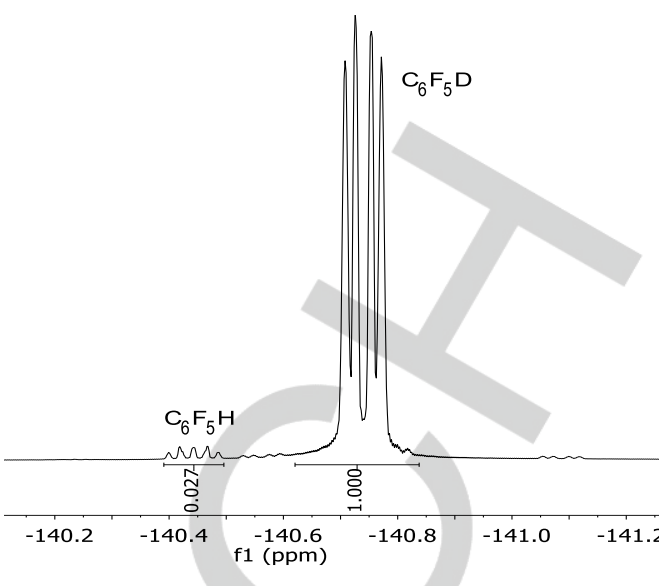

Figure $1 .{ }^{19} \mathrm{~F}$ NMR of a mixture of $\mathrm{C}_{6} \mathrm{~F}_{5} \mathrm{H}$ and $\mathrm{C}_{6} \mathrm{~F}_{5} \mathrm{D}$ (entry 1 , Table $1 ; \mathrm{F}_{\text {ortho }}$ region).

are longer ( $8 \mathrm{~h}$ to reach $99 \%$ crude yield). The standard conditions in Table 1 for acetone-d6 as deuterium source use a ratio $\mathrm{C}_{6} \mathrm{~F}_{5} \mathrm{H}$ :deuterated solvent $=1: 16$. The amount of acetoned6 can be reduced to a ratio as low as $1: 2$ to reach $90 \%$

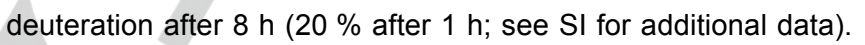
$\mathrm{C}_{6} \mathrm{~F}_{5} \mathrm{D}$ can be isolated in good yields by extraction of the acetone-d6 with water.

Table 1. $\mathrm{C}_{6} \mathrm{~F}_{5} \mathrm{D}$ from $\mathrm{C}_{6} \mathrm{~F}_{5} \mathrm{H}$ by $\mathrm{H} / \mathrm{D}$ exchange with a deuterated solvent. ${ }^{[\mathrm{a}]}$

\begin{tabular}{|c|c|c|c|c|}
\hline Entry & $\begin{array}{l}\text { Solvent/D- } \\
\text { source }\end{array}$ & Base (mol \%) & Additive (mol \%) & $\begin{array}{l}\text { Crude yield } \\
\mathrm{C}_{6} \mathrm{~F}_{5} \mathrm{D}(\%)^{[\mathrm{b}]}\end{array}$ \\
\hline 1 & acetone-d6 & $\mathrm{Cs}_{2} \mathrm{CO}_{3}(10)$ & - & 98 \\
\hline 2 & acetone-d6 & $\mathrm{Cs}_{2} \mathrm{CO}_{3}(3)$ & - & 98 \\
\hline 3 & acetone-d6 & $\mathrm{Cs}_{2} \mathrm{CO}_{3}(10)$ & TEMPO (30) & 97 \\
\hline 4 & acetone-d6 & $\mathrm{K}_{2} \mathrm{CO}_{3}(10)$ & - & 88 \\
\hline 5 & acetone-d6 & $\mathrm{Na}_{2} \mathrm{CO}_{3}(10)$ & - & 0 \\
\hline 6 & acetone-d6 & $\left(\mathrm{NBu}_{4}\right)_{2} \mathrm{CO}_{3}$ & - & 92 \\
\hline 7 & acetone-d6 & CsOAc (10) & & 0 \\
\hline 8 & acetone-d6 & CsF (10) & & 10 \\
\hline 9 & acetone-d6 & $\mathrm{K}_{3} \mathrm{PO}_{4}(10)$ & & 98 \\
\hline 10 & acetone-d6 & $\mathrm{K}_{2} \mathrm{HPO}_{4}(10)$ & & 0 \\
\hline 11 & acetone-d6 & $\mathrm{KH}_{2} \mathrm{PO}_{4}(10)$ & & 0 \\
\hline 12 & $\mathrm{D}_{2} \mathrm{O}$ & $\mathrm{Cs}_{2} \mathrm{CO}_{3}(10)$ & & $30^{[c]}$ \\
\hline 13 & $\mathrm{D}_{2} \mathrm{O}$ & $\mathrm{Cs}_{2} \mathrm{CO}_{3}(10)$ & $\mathrm{NBu}_{4} \mathrm{Cl}(10)$ & 94 \\
\hline 14 & DMSO-d6 & $\mathrm{Cs}_{2} \mathrm{CO}_{3}(10)$ & - & 10 \\
\hline
\end{tabular}

[a] Reaction conditions: $\mathrm{C}_{6} \mathrm{~F}_{5} \mathrm{H}(34 \mu \mathrm{L}, 0.3 \mathrm{mmol})$, deuterated solvent $(0.40$ $\mathrm{mL}, 4.96 \mathrm{mmol}$ acetone-d6, $5.7 \mathrm{mmol}$ DMSO-d6 or $22.2 \mathrm{mmol} \mathrm{D}_{2} \mathrm{O}$ ), base, 90 ${ }^{\circ} \mathrm{C}, 1 \mathrm{~h}$. [b] Crude yields were determined by integration of the $\mathrm{F}_{\text {ortho }}$ resonances in ${ }^{19} \mathrm{~F} \mathrm{NMR}$. [c] $97 \%$ yield was obtained in $18 \mathrm{~h}$. 
The reaction is not affected by the presence of TEMPO indicating that it does not follow a radical pathway (entry 3 , Table 1). It is not accelerated in the presence of a transition metal such as palladium. The use of $\left[\mathrm{Pd}(\right.$ bipy- $\left.6-\mathrm{OH}) \mathrm{Br}\left(\mathrm{C}_{6} \mathrm{~F}_{5}\right)\right]$ (bipy-6-OH = [2,2'-bipyridin]-6(1H)-one), a complex that has proved to be active in the $\mathrm{C}-\mathrm{H}$ functionalization of arenes,${ }^{[17]}$ has no effect on the deuteration rate. $\mathrm{Pd} / \mathrm{C}$, a form of palladium closer to a hypothetical contamination of the alkali carbonates does not increase the deuteration rate either. However, the reaction is clearly dependent on the strength of the base used and only carbonates and phosphates are effective, whereas weaker bases such as acetate, fluoride or hydrogenphosphates gave lower or no deuteration at all (cf. entries 1 and 7-11, Table 1). This points to an acid-base mechanism for the deuterium exchange. $\mathrm{D}_{2} \mathrm{O}$ can also act as deuterium source in this reaction, but the deuteration is slower (entry 12, Table 1) and a high conversion $(97 \%)$ is only obtained after $18 \mathrm{~h}$. This is most probably due to the low solubility of $\mathrm{C}_{6} \mathrm{~F}_{5} \mathrm{H}$ in water and, in fact, the presence of a phase transfer agent such as $\mathrm{NBu}_{4} \mathrm{Cl}$ leads to a reaction as fast as the deuteration in acetone-d6 (entry 13, Table 1). However, the mixture $\mathrm{D}_{2} \mathrm{O} / \mathrm{NBu}_{4} \mathrm{Cl}$ is less cost-effective than acetone and therefore the convenience of using $\mathrm{D}_{2} \mathrm{O}$ or acetone-d6 as deuterium source is a matter of reaction time. DMSO-d6 is less efficient that acetone (entry 14, Table 1).

The heavier alkali metal carbonates (cesium and potassium) are more efficient than sodium carbonate in acetone-d6 (entries 1, 4, 5 , Table 1). However no large differences are observed when the three carbonates are used in $\mathrm{D}_{2} \mathrm{O}$; in the same conditions as entry 12 , Table 1 , the conversions to $\mathrm{C}_{6} \mathrm{~F}_{5} \mathrm{D}$ in $2 \mathrm{~h}$ are: $56 \%$ $\left(\mathrm{Cs}^{+}\right), 68 \%\left(\mathrm{~K}^{+}\right), 50 \%\left(\mathrm{Na}^{+}\right)$. Tetrabutylammonium carbonate is also efficient in acetone (entry 6, Table 1 ). The large differences observed in acetone upon change of the cation cannot be directly correlated with the solubility of the salts and may reflect the stabilization of ionic pairs in a less solvating medium than water, whereas those ion-pair species may be irrelevant in the latter. A plausible mechanism for the exchange that involves deprotonation of the deuterated solvent and $\mathrm{C}_{6} \mathrm{~F}_{5} \mathrm{H}$ with the base is represented in Scheme 2. ${ }^{[18]}$

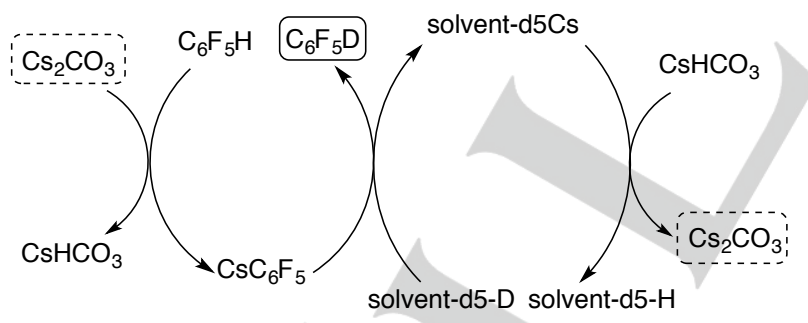

solvent $=$ acetone

Scheme 2. Base-promoted $\mathrm{H}-\mathrm{D}$ exchange between $\mathrm{C}_{6} \mathrm{~F}_{5} \mathrm{H}$ and acetone-d6.

It is worth noting that in the course of other studies, several observations are reported in the literature of deuterium exchange of pentafluorobenzene and $\mathrm{D}_{2} \mathrm{O}$ in the presence of a carboxylate, ${ }^{[19]}$ or other bases. ${ }^{[20]}$ Also, DMSO-d6 has been identified as the deuterium source, in a side reaction that involves the deuteration of fluorobenzene. ${ }^{[21]}$

Other fluoroarenes were also tested. Interestingly, neither acetone-d6 nor $\mathrm{D}_{2} \mathrm{O}$ were suitable deuterium sources and, for example, in the conditions of entry 1 , Table 1 , only $30 \%$ conversion of 1,3,5-trifluorobenzene was achieved and no deuteration of 1, 3-difluorobenzene was observed. However, the reactions work well with DMSO-d6. As can be seen in Table 2, several fluoroaryls can be deuterated in good yields.

Table 2. Deuteration of fluoroaryls by H/D exchange with DMSO-d6. ${ }^{[a]}$

\begin{tabular}{|c|c|c|c|c|c|}
\hline Entry & Fluoroarene $^{[b]}$ & $\begin{array}{l}\text { Base } \\
(\mathrm{mol} \%)\end{array}$ & $\mathrm{T}\left({ }^{\circ} \mathrm{C}\right)$ & time $(\mathrm{h})$ & $\begin{array}{l}\% \text { deuteration yield: } \\
\text { crude (isolated) }{ }^{[\mathrm{c}]}\end{array}$ \\
\hline 1 & & $\begin{array}{l}\mathrm{Cs}_{2} \mathrm{CO}_{3} \\
(10)\end{array}$ & 90 & & $90(88)$ \\
\hline 2 & & $\begin{array}{l}\mathrm{Cs}_{2} \mathrm{CO}_{3} \\
(10)\end{array}$ & 90 & 1 & $\begin{array}{l}99(83)(\text { monoD:diD = } \\
1: 20)\end{array}$ \\
\hline 3 & & $\begin{array}{l}\mathrm{Cs}_{2} \mathrm{CO}_{3} \\
(10)\end{array}$ & 90 & 1 & $\begin{array}{l}99(91)(\text { monoD:diD = } \\
1: 20)\end{array}$ \\
\hline 4 & & $\begin{array}{l}\mathrm{Cs}_{2} \mathrm{CO}_{3} \\
(10)\end{array}$ & 90 & 1 & $\begin{array}{l}99(89) \\
\text { (triD:diD = 24:1) }\end{array}$ \\
\hline 5 & & $\begin{array}{l}\mathrm{Cs}_{2} \mathrm{CO}_{3} \\
(10)\end{array}$ & 90 & 1 & $98(96)$ \\
\hline 6 & & $\begin{array}{l}\mathrm{K}_{3} \mathrm{PO}_{4} \\
(100)\end{array}$ & 130 & 24 & $99(88)$ \\
\hline 7 & & $\begin{array}{l}\mathrm{K}_{3} \mathrm{PO}_{4} \\
(100)\end{array}$ & 130 & 24 & $\begin{array}{l}99(85) \\
(\text { monoD:diD = 1:10) }\end{array}$ \\
\hline 8 & & $\begin{array}{l}\mathrm{K}_{3} \mathrm{PO}_{4} \\
(100)\end{array}$ & 130 & 72 & $\begin{array}{l}99(87) \\
(\operatorname{monoD}: \mathrm{diD}=1: 12)\end{array}$ \\
\hline 9 & $\mathrm{De}$ & $\begin{array}{l}\mathrm{Cs}_{2} \mathrm{CO}_{3} \\
(10)\end{array}$ & 90 & 3 & $\begin{array}{l}76(72) \\
\text { (protio:monoD:diD:triD } \\
=9: 76: 14: 1 \text { ) }\end{array}$ \\
\hline 10 & & $\begin{array}{l}\mathrm{Cs}_{2} \mathrm{CO}_{3} \\
\text { (10) }\end{array}$ & 130 & 72 & $59(52)$ \\
\hline 11 & & $\mathrm{~K}_{3} \mathrm{PO}_{4}(50)$ & 130 & $24 \mathrm{~h}$ & $98(86)$ \\
\hline 12 & & $\mathrm{NaOH}(50)$ & 130 & $24 \mathrm{~h}$ & $98(90)$ \\
\hline
\end{tabular}

[a] Reaction conditions: fluoroarene $(5 \mathrm{mmol}), \mathrm{DMSO}-\mathrm{d} 6(5.6 \mathrm{~mL}, 80 \mathrm{mmol})$, base, $90^{\circ} \mathrm{C}$ or $130{ }^{\circ} \mathrm{C}$. [b] Site of deuteration is marked with dots. [c] Crude yields and isomer ratios were determined by integration of the $F_{\text {ortho }}$ resonances in ${ }^{19} \mathrm{~F}$ NMR or by ${ }^{1} \mathrm{H}$ NMR.

The ease of H/D exchange and the site of deuteration is controlled by the acidity of the $\mathrm{C}-\mathrm{H}$ bonds, i.e. the number of fluorine atoms in the molecule and the presence of ortho-F. Catalytic amounts of cesium carbonate and moderate temperatures are sufficient for the deuteration of tetra-, tri- and 
1, 3-difluorobenzenes. 1, 2-Difluorobenzene (only one ortho- $F$ to the $\mathrm{C}-\mathrm{H}$ bond) and the monofluoroarenes require a stronger base $\left(\mathrm{K}_{3} \mathrm{PO}_{4}\right)$ and higher temperatures.

Complete deuteration was observed for the more acidic fluoroarenes (entries 1-4, Table 2). Selective deuteration of those $\mathrm{C}-\mathrm{H}$ bonds ortho to a $\mathrm{C}-\mathrm{F}$ bond, i.e. the more acidic ones due to inductive effects, occurs (entries 5-8, Table 2). The deuterated $p$-bromofluorobenzene (entry 8 , Table 2) is an interesting starting material to introduce a deuterated fluoroarene by subsequent Pd-catalyzed cross coupling reactions. The isolation of all deuterated arenes by distillation is extremely simple due to the high boiling point of DMSO.

The possibility of controlling the degree of deuteration was tested with 1,3,5-trifluorobenzene, changing the ratio fluoroarene:DMSO-d6. Although an increase of this ratio also increased the amount of mono and di-deuterated arenes, it was not possible to selectively obtain one over the other (see SI).

We tested our system with other fluorinated substrates that bear additional functional groups. 3,5-Difluoroanisole can be selectively deuterated under the conditions of entry 9 , Table 2 , to give the monodeuterated 3,5-difluoro(4- $d$ )anisole as the major product $(76 \%)$ along with small amounts of the di- and trideuterated derivatives (see $\mathrm{SI}$ ). The ester or cyano groups undergo partial hydrolysis under our reaction conditions, but the monodeuterated ethyl 3,5-difluoro(4-d)-benzoate can still be selectively obtained in $52 \%$ isolated yield from ethyl 3,5-difluorobenzoate (entry 10, Table 2). The deuteration of 3,5-difluorobenzonitrile in the conditions of entry 2 , Table 2 , is less selective and similar ratios of the mono, di and tri-deuterated compounds are observed, which makes the reaction less attractive synthetically.

Other non-fluorinated substrates were tested and we found out that thiophene and furane can be selectively dideuterated in the more acidic 2, 5 positions (entries 11, 12, Table 2). Arenes such as chlorobenzene or benzonitrile did not react. The basepromoted deuteration using DMSO-d6 has been used before to prepare very specifically deuterated derivatives such as benzylic amines, triazoles, and alkenes. ${ }^{[22]}$

The deuteration reaction is controlled by the relative acidity of the fluoroarene and the solvent. Several reported experimental and calculated $\mathrm{pK}_{\mathrm{a}}$ values for $\mathrm{C}_{6} \mathrm{~F}_{\mathrm{n}} \mathrm{H}_{6-\mathrm{n}}$ derivatives can be found in the literature under different conditions. ${ }^{[23]}$ However, since values are not available for all the arenes tested in this work, we decided to calculate them, for comparison purposes only, by evaluating the Gibbs energy of the reaction shown in Eq. 2 using DFT methods. The calculations were carried out using the M06 functional and the continuum SMD model for the solvent at 90 ${ }^{\circ} \mathrm{C}$ (see Experimental Section).

$$
\begin{gathered}
\mathrm{ArH}+\text { solvent } \\
\text { solvent }=\mathrm{DMSO}, \text { acetone }
\end{gathered} \mathrm{Ar}^{-}+\mathrm{D}^{\circ} \mathrm{C} \text { solvent } \mathrm{H}^{+}
$$

The energy values obtained lead to the $\mathrm{pK}_{\mathrm{a}} \mathrm{s}$ shown in Figure 2. They show that, as mentioned above, the acidity of the $\mathrm{C}-\mathrm{H}$ bonds in the fluoroarenes is determined by inductive effects of the ortho- $\mathrm{F}$ atoms and the total number of fluorine in the ring. The trend is consistent with the one extracted from the values in the literature. ${ }^{[23]}$

The position marked in Figure 2 for each case is the most acidic one. The $\mathrm{pK}_{\mathrm{a}}$ of the $\mathrm{C}-\mathrm{H}$ bond in other positions was also calculated and, for example, the values for fluorobenzene are: o, $m, p=37.1,41.8,42.8$. It is clear that deuteration only occurs for the more acidic positions of each fluoroarene (Table 2 and Figure 2). For the less acidic $\mathrm{C}-\mathrm{H}$ bonds $\left(\mathrm{pK}_{\mathrm{a}} \geq 35\right.$ in our calculations) stronger bases are required and those arenes that could not be deuterated have calculated $\mathrm{pK}_{\mathrm{a}} \mathrm{s}$ about 40 (DMSO). The $\mathrm{pK}_{\mathrm{a}}$ values in acetone are higher than those in DMSO as expected for the stronger basic character of DMSO.$^{[24]}$ In DMSO, the arenes are more acidic than the solvent (calculated $\left.\mathrm{pK}_{\text {ion(DMSO) }}=38.1\right),{ }^{[25]}$ they can undergo deprotonation and most arenes can be deuterated following a pathway similar to the one represented in Scheme 2 (solvent = DMSO). A good match between the acidities of solvent and the arene might be necessary for an efficient exchange. This may be one of the reasons for the lower deuteration of pentafluorobenzene observed with DMSO-d6: $\mathrm{C}_{6} \mathrm{~F}_{5} \mathrm{H}$ is way more acidic than the solvent and the concentration of DMSO deprotonated species might not be enough for an efficient entrance of deuterium in the exchange.

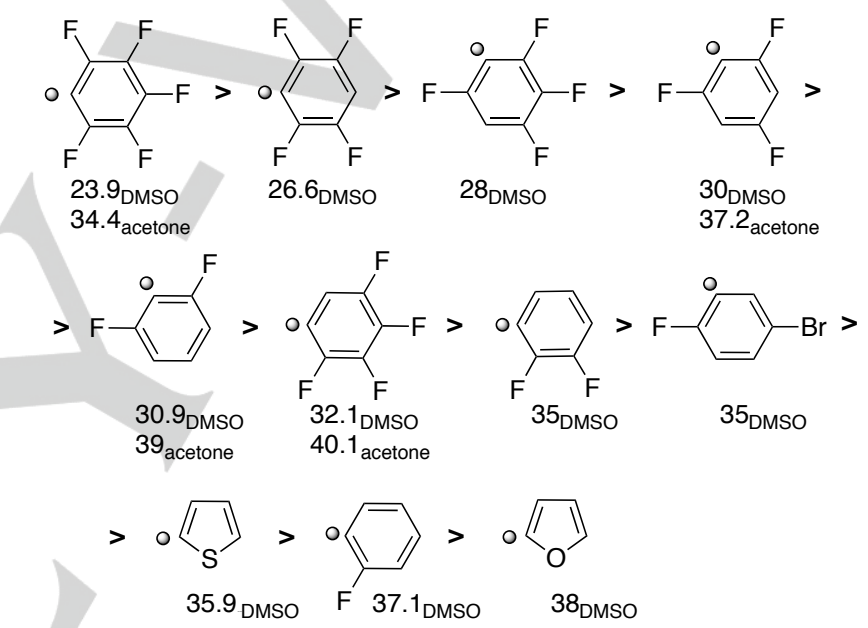

Figure 2. Trend in acidity of the marked $\mathrm{C}-\mathrm{H}$ bonds of fluoroarenes or heterocycles. Values correspond to $\mathrm{pK}_{\mathrm{a}} \mathrm{s}$ calculated by DFT in the specified solvent according to Eq. 2.

\section{Conclusion}

The H/D exchange of moderately acidic $\mathrm{C}-\mathrm{H}$ bonds of arenes and heteroarenes can be expected with moderately acidic deuterated solvents in the presence of even a weak base in catalytic amounts. Taking advantage of the exchange we have developed a convenient, cost-effective and sustainable preparation of deuterium labeled fluoroarenes. It is also very important to be aware of this fact in studies that use deuterium exchange as mechanistic probes. Reaction conditions that can be related to those reported here are quite common, for example, in coupling reactions that involve $\mathrm{C}-\mathrm{H}$ cleavage and other metal catalyzed synthetic protocols.

\section{Experimental Section}

\section{Materials and General Considerations}

${ }^{1} \mathrm{H},{ }^{13} \mathrm{C}\left\{{ }^{1} \mathrm{H}\right\}$ and ${ }^{19} \mathrm{~F}$ NMR spectra were recorded on Bruker AV-400 or Agilent MR-500 spectrometers at the Laboratorio de Técnicas 
Instrumentales (LTI, UVa). Chemical shifts (in $\delta$ units, ppm) were referenced to $\mathrm{SiMe}_{4}\left({ }^{1} \mathrm{H}\right.$ and $\left.{ }^{13} \mathrm{C}\right)$ and $\mathrm{CFCl}_{3}\left({ }^{19} \mathrm{~F}\right)$. The spectral data were recorded at $293 \mathrm{~K}$ unless otherwise noted. The GC-MS analyses were performed in a Thermo-Scientific Focus DSQ II GC/MS apparatus. The intensities are reported as percentages relative to the base peak after the corresponding $\mathrm{m} / \mathrm{z}$ value. Deuteration reactions were carried out in Schlenk flasks with constant stirring. To avoid metal contamination, both the magnetic bar and the Schlenk flasks were cleaned twice with aqua regia prior to use. Cesium carbonate, Potassium phosphate, sodium hydroxide, tetrabutylammonium chloride, all the fluoroarenes, thiophene and furane are commercially available and were purchased from Aldrich, Alfa Aesar or Fluorochem. Deuterated solvents (DMSO-d6, acetone-d6, $\mathrm{D}_{2} \mathrm{O}$ ) were provided by Eurisotop. All commercial reagents and solvents were used as received unless otherwise indicated. Tetrabutylammonium carbonate was prepared according to the procedure in the literature. ${ }^{[26]}$

\section{Deuteration of pentafluorobenzene}

Cesium carbonate $(78.0 \mathrm{mg}, 0.24 \mathrm{mmol})$ was introduced in Schlenk flask with a screw cap in a nitrogen atmosphere. Then, acetone-d6 $(2.5 \mathrm{~mL}$, $31.2 \mathrm{mmol}$ ) and pentafluorobenzene $(870 \mu \mathrm{L}, 7.8 \mathrm{mmol})$ were added. The mixture was kept in a pre-heated bath at $90^{\circ} \mathrm{C}$ during $4 \mathrm{~h}$. After that time, total conversion was observed, as checked by ${ }^{19} \mathrm{~F}$ NMR of the crude mixture. The deuterated pentafluorobenzene, was purified by an extraction of the acetone-d6 with water in a liquid-liquid extraction. Yield: $0.95 \mathrm{~g}(75 \%)$. NOTE: The reaction works in shorter times at the expense of using a higher amount of acetone-d6. In the same conditions described above, using $62 \mathrm{mmol}$ of acetone- $\mathrm{d} 6(4.7 \mathrm{~mL})$ the reaction is complete in $1 \mathrm{~h}$.

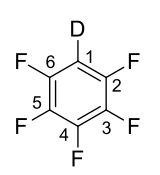

${ }^{13} \mathrm{C}\left\{{ }^{1} \mathrm{H}\right\}$ NMR $\left(125.67 \mathrm{MHz}, \delta, \mathrm{CDCl}_{3}\right): 146.1\left(\mathrm{dm},{ }^{1} \mathrm{~J}_{\mathrm{C}-\mathrm{F}}=\right.$ $\left.248.3 \mathrm{~Hz}, \mathrm{C}^{2}, \mathrm{C}^{6}\right), 141.7\left(\mathrm{dm},{ }^{1} \mathrm{~J}_{\mathrm{C}-\mathrm{F}}=253.1 \mathrm{~Hz}, \mathrm{C}^{4}\right), 137.5$ $\left(\mathrm{dm},{ }^{1} \mathrm{~J}_{\mathrm{C}-\mathrm{F}}=252.3 \mathrm{~Hz}, \mathrm{C}^{3}, \mathrm{C}^{5}\right), 100.5\left(\mathrm{~m}, \mathrm{C}^{1}\right) .{ }^{19} \mathrm{~F}$ NMR $\left(470.17 \mathrm{MHz}, \delta, \mathrm{CDCl}_{3}\right):-139.02\left(\mathrm{~m}, 2 \mathrm{~F}, \mathrm{~F}_{\text {ortho }}\right),-153.80(\mathrm{t}$ $\left.{ }^{3} J_{F-F}=20.8 \mathrm{~Hz}, 1 \mathrm{~F}, \mathrm{~F}_{\text {para }}\right),-162.19\left(\mathrm{~m}, 2 \mathrm{~F}, \mathrm{~F}_{\text {meta }}\right) . M S(E I$, $70 \mathrm{eV}): \mathrm{m} / \mathrm{z}(\%) 169(100)\left[\mathrm{M}^{+}\right], 138(15), 100(70)$.

\section{Deuteration of 1,3-difluorobenzene, tri- , and tetrafluorobenzenes.}

Cesium carbonate (162.9 mg, $0.5 \mathrm{mmol}$ ) was introduced in Schlenk flask with a screw cap in a nitrogen atmosphere. Then, DMSO-d6 $(5.6 \mathrm{~mL}, 80$ $\mathrm{mmol}$ ) and the corresponding fluoroarene $(5 \mathrm{mmol})$ were added. The mixture was kept in a pre-heated bath at $90^{\circ} \mathrm{C}$ during $1 \mathrm{~h}$. After that time, total conversion was observed, as checked by ${ }^{19} \mathrm{~F}$ NMR of the crude mixture. The deuterated fluoroarenes were purified by flash distillation under vacuum, collecting the product by freezing in liquid nitrogen. All of them were obtained as colorless liquids and with good yields (see Table 2).<smiles>[2H]c1c(F)cccc1F</smiles>

${ }^{1} \mathrm{H}$ NMR $\left(499.73 \mathrm{MHz}, \delta, \mathrm{CDCl}_{3}\right): 7.29\left(\mathrm{~m}, 1 \mathrm{H}, \mathrm{H}^{5}\right), 6.87(\mathrm{~m}$, $\left.2 \mathrm{H}, \mathrm{H}^{4}, \mathrm{H}^{6}\right) \cdot{ }^{13} \mathrm{C}\left\{{ }^{1} \mathrm{H}\right\}$ NMR $\left(125.67 \mathrm{MHz}, \delta, \mathrm{CDCl}_{3}\right): 163.1$ $\left(\mathrm{dd},{ }^{1} \mathrm{~J}_{\mathrm{C}-\mathrm{F}}=249.6 \mathrm{~Hz},{ }^{3} \mathrm{~J}_{\mathrm{C}-\mathrm{F}}=10 \mathrm{~Hz}, \mathrm{C}^{1}, \mathrm{C}^{3}\right), 130.6\left(\mathrm{t},{ }^{3} \mathrm{~J}_{\mathrm{C}-\mathrm{F}}\right.$ $\left.=10 \mathrm{~Hz}, \mathrm{C}^{5}\right), 111.2\left(\mathrm{~m}, \mathrm{C}^{4}, \mathrm{C}^{6}\right), 103.8\left(\mathrm{~m},{ }^{1} \mathrm{~J}_{\mathrm{C}-\mathrm{D}}={ }^{2} \mathrm{~J}_{\mathrm{C}-\mathrm{F}}=\right.$ $\left.25.5 \mathrm{~Hz}, \mathrm{C}^{2}\right) .{ }^{19} \mathrm{~F} \mathrm{NMR}\left(470.17 \mathrm{MHz}, \delta, \mathrm{CDCl}_{3}\right):-110.28(\mathrm{~m}$ 2F). MS (El, $70 \mathrm{eV}): \mathrm{m} / \mathrm{z}(\%) 115$ (100) $\left[\mathrm{M}^{+}\right], 64$ (65).<smiles>[2H]c1c(F)c(F)c([2H])c(F)c1F</smiles>

${ }^{13} \mathrm{C}\left\{{ }^{1} \mathrm{H}\right\}$ NMR $\left(125.67 \mathrm{MHz}, \delta, \mathrm{CDCl}_{3}\right): 163.2\left(\mathrm{dt},{ }^{1} \mathrm{~J}_{\mathrm{C}-\mathrm{F}}=\right.$ $\left.249.6 \mathrm{~Hz},{ }^{3} \mathrm{~J}_{\mathrm{C}-\mathrm{F}}=15 \mathrm{~Hz}, \mathrm{C}^{1}, \mathrm{C}^{3}, \mathrm{C}^{5}\right), 99.9\left(\mathrm{~m}, \mathrm{C}^{2}, \mathrm{C}^{4}, \mathrm{C}^{6}\right)$. ${ }^{19} \mathrm{~F} \mathrm{NMR}\left(470.17 \mathrm{MHz}, \delta, \mathrm{CDCl}_{3}\right):-108.10$ (s, 3F). MS (El, $70 \mathrm{eV}): \mathrm{m} / \mathrm{z}(\%) 135(80)\left[\mathrm{M}^{+}\right], 83(90), 66$ (100).

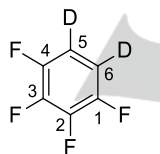

${ }^{13} \mathrm{C}\left\{{ }^{1} \mathrm{H}\right\}$ NMR (125.67 MHz, $\left.\delta, \mathrm{CDCl}_{3}\right): 147.4\left(\mathrm{dm},{ }^{1} \mathrm{~J}_{\mathrm{C}-\mathrm{F}}=\right.$ $\left.251.9 \mathrm{~Hz}, \mathrm{C}^{1}, \mathrm{C}^{4}\right), 140.8\left(\mathrm{dm},{ }^{1} \mathrm{~J}_{\mathrm{C}-\mathrm{F}}=254.9 \mathrm{~Hz}, \mathrm{C}^{2}, \mathrm{C}^{3}\right)$, $110.8\left(\mathrm{~m}, \mathrm{C}^{5}, \mathrm{C}^{6}\right) .{ }^{19} \mathrm{~F}$ NMR $\left(470.17 \mathrm{MHz}, \delta, \mathrm{CDCl}_{3}\right)$ : $139.75\left(\mathrm{~m}, 2 \mathrm{~F}, \mathrm{~F}^{1}, \mathrm{~F}^{4}\right),-156.06\left(\mathrm{~m}, 2 \mathrm{~F}, \mathrm{~F}^{2}, \mathrm{~F}^{3}\right)$. MS (EI, 70 $\mathrm{eV}): \mathrm{m} / \mathrm{z}(\%) 152(100)\left[\mathrm{M}^{+}\right], 83(40)$.

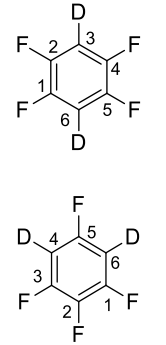

${ }^{13} \mathrm{C}\left\{{ }^{1} \mathrm{H}\right\}$ NMR $\left(125.67 \mathrm{MHz}, \delta, \mathrm{CDCl}_{3}\right): 145.8\left(\mathrm{dm},{ }^{1} \mathrm{~J}_{\mathrm{C}-\mathrm{F}}=\right.$ $\left.250 \mathrm{~Hz}, \mathrm{C}^{1}, \mathrm{C}^{2}, \mathrm{C}^{4}, \mathrm{C}^{5}\right), 105.9\left(\mathrm{~m}, \mathrm{C}^{3}, \mathrm{C}^{6}\right) .{ }^{19} \mathrm{~F}$ NMR $(470.17$ $\mathrm{MHz}, \delta, \mathrm{CDCl}_{3}$ ): -140.19 (s, 4F). MS (El, $\left.70 \mathrm{eV}\right): \mathrm{m} / \mathrm{z}(\%)$ $152(100)\left[\mathrm{M}^{+}\right], 83(40)$.

${ }^{13} \mathrm{C}\left\{{ }^{1} \mathrm{H}\right\}$ NMR $\left(125.67 \mathrm{MHz}, \delta, \mathrm{CDCl}_{3}\right): 156.9\left(\mathrm{dm},{ }^{1} \mathrm{~J}_{\mathrm{C}-\mathrm{F}}=\right.$ $249.2 \mathrm{~Hz}, \mathrm{C}^{5}$ ), 151.1 (dddd, ${ }^{1} \mathrm{~J}_{\mathrm{C}-\mathrm{F}}=251.3 \mathrm{~Hz},{ }^{2} \mathrm{~J}_{\mathrm{C}-\mathrm{F}}=15 \mathrm{~Hz}$ $\left.{ }^{3} \mathrm{~J}_{\mathrm{C}-\mathrm{F}}=11 \mathrm{~Hz},{ }^{3} \mathrm{~J}_{\mathrm{C}-\mathrm{F}}=5.3 \mathrm{~Hz}, \mathrm{C}^{1}, \mathrm{C}^{3}\right), 137.3\left(\mathrm{dtd},{ }^{1} \mathrm{~J}_{\mathrm{C}-\mathrm{F}}=\right.$ $\left.247.4 \mathrm{~Hz},{ }^{2} \mathrm{~J}_{\mathrm{C}-\mathrm{F}}=15.4 \mathrm{~Hz},{ }^{4} \mathrm{~J}_{\mathrm{C}-\mathrm{F}}=5.1 \mathrm{~Hz}, \mathrm{C}^{2}\right), 100.9\left(\mathrm{~m},{ }^{1} \mathrm{~J}_{\mathrm{C}-}\right.$ $\left.{ }_{D}={ }^{2} \mathrm{~J}_{\mathrm{C}-\mathrm{F}}=25.5 \mathrm{~Hz}, \mathrm{C}^{4}, \mathrm{C}^{6}\right) .{ }^{19} \mathrm{~F}$ NMR $(470.17 \mathrm{MHz}, \delta$, $\left.\mathrm{CDCl}_{3}\right):-114.37\left(\mathrm{~d},{ }^{5} \mathrm{~J}_{\mathrm{F}-\mathrm{F}}=10.5 \mathrm{~Hz}, 1 \mathrm{~F}, \mathrm{~F}^{5}\right),-131.90\left(\mathrm{~d},{ }^{3} \mathrm{~J}_{\mathrm{F}-\mathrm{F}}=20.4 \mathrm{~Hz} 2 \mathrm{~F}\right.$, $\left.\mathrm{F}^{1}, \mathrm{~F}^{3}\right),-165.99\left(\mathrm{td},{ }^{3} \mathrm{~J}_{\mathrm{F}-\mathrm{F}}=20.4,{ }^{5} \mathrm{~J}_{\mathrm{F}-\mathrm{F}}=10.5 \mathrm{~Hz}, 1 \mathrm{~F}, \mathrm{~F}^{2}\right)$. MS (El, $\left.70 \mathrm{eV}\right)$ : $\mathrm{m} / \mathrm{z}(\%) 152(65)\left[\mathrm{M}^{+}\right], 121(45), 83(100)$

\section{Deuteration of fluorobenzene, 1,2-difluorobenzene and 1-fluoro-4-} bromobenzene.

Potassium phosphate $(1.06 \mathrm{~g}, 5 \mathrm{mmol})$ was introduced in Schlenk flask with a screw cap in a nitrogen atmosphere. Then, DMSO-d6 $(5.6 \mathrm{~mL}, 80$ $\mathrm{mmol})$ and the corresponding fluoroarene $(5 \mathrm{mmol})$ were added. The mixture was kept in a pre-heated bath at $130{ }^{\circ} \mathrm{C}$ during $24 \mathrm{~h}$ for fluorobenzene and 1,2-difluorobenzene and during $72 \mathrm{~h}$ for 1-fluoro-4bromobenzene. After that time, total conversion was observed, as checked by ${ }^{19} \mathrm{~F}$ NMR of the crude mixture. The deuterated fluoroarenes were purified by flash distillation under vacuum, collecting the product by freezing in liquid nitrogen. The total purification of 1-bromo-4-fluoro$3,5\left(d_{2}\right)$-benzene was carried out by column chromatography in silica using dichloromethane as eluent. All products were obtained as colorless liquids and with good yields (see Table 2).

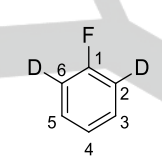

${ }^{1} \mathrm{H}$ NMR (499.73 MHz, $\left.\delta, \mathrm{CDCl}_{3}\right): 7.34\left(\mathrm{~m}, 2 \mathrm{H}, \mathrm{H}^{3}, \mathrm{H}^{5}\right), 7.14$ $\left(\mathrm{t},{ }^{3} \mathrm{~J}_{\mathrm{H}-\mathrm{H}}=7.4 \mathrm{~Hz}, 1 \mathrm{H}, \mathrm{H}^{4}\right) .{ }^{13} \mathrm{C}\left\{{ }^{1} \mathrm{H}\right\}$ NMR $(125.67 \mathrm{MHz}, \delta$, $\left.\mathrm{CDCl}_{3}\right): 162.8\left(\mathrm{~d},{ }^{1} \mathrm{~J}_{\mathrm{C}-\mathrm{F}}=248.7 \mathrm{~Hz}, \mathrm{C}^{1}\right), 129.8\left(\mathrm{~d},{ }^{3} \mathrm{~J}_{\mathrm{C}-\mathrm{F}}=7.8\right.$ $\left.\mathrm{Hz}, \mathrm{C}^{3}, \mathrm{C}^{5}\right), 123.9\left(\mathrm{C}^{4}\right), 115\left(\mathrm{~m},{ }^{1} \mathrm{~J}_{\mathrm{C}-\mathrm{D}}=25 \mathrm{~Hz},{ }^{2} \mathrm{~J}_{\mathrm{C}-\mathrm{F}}=20 \mathrm{~Hz}\right.$, $\left.\mathrm{C}^{2}, \mathrm{C}^{6}\right) \cdot{ }^{19} \mathrm{~F}$ NMR $\left(470.17 \mathrm{MHz}, \delta, \mathrm{CDCl}_{3}\right):-113.67\left(\mathrm{t},{ }^{4} \mathrm{~J}_{\mathrm{F}-\mathrm{H}}=\right.$ $5.8 \mathrm{~Hz}, 1 \mathrm{~F})$. MS (El, $70 \mathrm{eV}): \mathrm{m} / \mathrm{z}(\%) 98(100)\left[\mathrm{M}^{+}\right], 71$ (74).

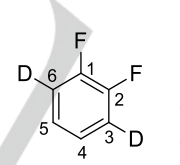

${ }^{1} \mathrm{H}$ NMR (499.73 MHz, $\left.\delta, \mathrm{CDCl}_{3}\right): 7.07\left(\mathrm{~m}, \mathrm{H}^{4}, \mathrm{H}^{5}\right) .{ }^{13} \mathrm{C}\left\{{ }^{1} \mathrm{H}\right\}$ NMR (125.67 MHz, $\left.\delta, \mathrm{CDCl}_{3}\right): 150.5$ (dd, ${ }^{1} \mathrm{~J}_{\mathrm{C}-\mathrm{F}}=250 \mathrm{~Hz}$, $\left.{ }^{2} \mathrm{~J}_{\mathrm{C}-\mathrm{F}}=13.6 \mathrm{~Hz}, \mathrm{C}^{1}, \mathrm{C}^{2}\right), 124.4\left(\mathrm{~m},{ }^{3} \mathrm{~J}_{\mathrm{C}-\mathrm{F}}={ }^{4} \mathrm{~J}_{\mathrm{C}-\mathrm{F}}=5.2 \mathrm{~Hz}\right.$, $\left.{ }^{2} \mathrm{~J}_{\mathrm{C}-\mathrm{D}}=1.5 \mathrm{~Hz}, \mathrm{C}^{4}\right), 117.1\left(\mathrm{~m},{ }^{1} \mathrm{~J}_{\mathrm{C}-\mathrm{D}}=24.9,{ }^{2} \mathrm{~J}_{\mathrm{C}-\mathrm{F}}=12 \mathrm{~Hz}\right.$, $\left.{ }^{3} \mathrm{~J}_{\mathrm{C}-\mathrm{F}}=5.3 \mathrm{~Hz}, \mathrm{C}^{3}, \mathrm{C}^{6}\right) .{ }^{19} \mathrm{~F}$ NMR $\left(470.17 \mathrm{MHz}, \delta, \mathrm{CDCl}_{3}\right)$ : 138.73 (bs). MS (El, 70 eV): m/z (\%) 116 (100) [M+], 100 (18), 71 (60), 57 (78).<smiles>[2H]c1cc(Br)cc(Br)c1F</smiles>

${ }^{1} \mathrm{H}$ NMR (499.73 MHz, $\left.\delta, \mathrm{CDCl}_{3}\right): 7.44\left(\mathrm{~d},{ }^{4} \mathrm{~J}_{\mathrm{H}-\mathrm{F}}=5.1 \mathrm{~Hz}\right.$, $\left.2 \mathrm{H}, \mathrm{H}^{2}, \mathrm{H}^{6}\right) \cdot{ }^{13} \mathrm{C}\left\{{ }^{1} \mathrm{H}\right\}$ NMR $\left(125.67 \mathrm{MHz}, \delta, \mathrm{CDCl}_{3}\right): 161.8$ $\left(\mathrm{d},{ }^{1} \mathrm{~J}_{\mathrm{C}-\mathrm{F}}=248.4 \mathrm{~Hz}, \mathrm{C}^{4}\right), 132.8\left(\mathrm{~d},{ }^{3} \mathrm{~J}_{\mathrm{C}-\mathrm{F}}=8 \mathrm{~Hz}, \mathrm{C}^{2}, \mathrm{C}^{6}\right)$, $117\left(\mathrm{~m}, \mathrm{C}^{3}, \mathrm{C}^{5}\right), 116.4\left(\mathrm{C}^{1}\right) .{ }^{9} \mathrm{~F}$ NMR $(470.17 \mathrm{MHz}, \delta$, $\left.\mathrm{CDCl}_{3}\right):-115.9 .(\mathrm{bs})$.

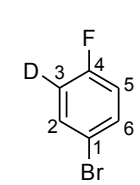

The minor isomer monoD, could not be completely characterized (8\%). ${ }^{1} \mathrm{H}$ NMR (499.73 MHz, $\left.\delta, \mathrm{CDCl}_{3}\right)$ : 7.44, 6.95. ${ }^{13} \mathrm{C}\left\{{ }^{1} \mathrm{H}\right\}$ NMR $\left(125.67 \mathrm{MHz}, \delta, \mathrm{CDCl}_{3}\right): 132.5$ $\left(\mathrm{d},{ }^{3} \mathrm{~J}_{\mathrm{C}-\mathrm{F}}=8 \mathrm{~Hz}, \mathrm{C}^{2}\right), 132.3\left(\mathrm{~d},{ }^{3} \mathrm{~J}_{\mathrm{C}-\mathrm{F}}=8 \mathrm{~Hz}, \mathrm{C}^{6}\right), 116.3(\mathrm{~d}$, $\left.{ }^{2} \mathrm{~J}_{\mathrm{C}-\mathrm{F}}=13 \mathrm{~Hz}, \mathrm{C}^{5}\right) .{ }^{9} \mathrm{~F}$ NMR $\left(470.17 \mathrm{MHz}, \delta, \mathrm{CDCl}_{3}\right)$ : 115.64 .

\section{Deuteration of ethyl 3,5-difluorobenzoate}

Cesium carbonate $(213.7 \mathrm{mg}, 0.66 \mathrm{mmol})$ was introduced in a Schlenk flask with a screw cap in a nitrogen atmosphere. Then, DMSO-d6 (3.7 $\mathrm{mL}, 52.5 \mathrm{mmol})$ and ethyl 3,5-difluorobenzoate $(0.5 \mathrm{~mL}, 3.28 \mathrm{mmol})$ were added. The mixture was kept in a pre-heated bath at $130^{\circ} \mathrm{C}$ during $72 \mathrm{~h}$. After that time, the following mixture of compounds given below was observed in the crude of the reaction by ${ }^{19} \mathrm{~F}$ NMR: ethyl 3,5-difluoro- $4(d)$ benzoate (59\%), 3,5-difluoro-4(d)-benzoic acid (28\%), ethyl 3,5-difluoro- 
benzoate $(4 \%)$ and 3,5-difluoro-benzoic acid (9\%). The monodeuterated ester, ethyl 3,5-difluoro-4(d)-benzoate, was separated by column chromatography in neutral alumina using a mixture of hexane:AcOEt (20:1) as mobile phase. Yield: $315 \mathrm{mg}(52 \%)$

$$
\text { Fot }
$$

${ }^{1} \mathrm{H}$ NMR $\left(499.73 \mathrm{MHz}, \delta, \mathrm{CDCl}_{3}\right): 7.53\left(\mathrm{~m}, 2 \mathrm{H}, \mathrm{H}^{2}, \mathrm{H}^{6}\right)$ 4.38 (q, J = 7.7 Hz, 2H, CH 2 ), 1.39 (t, J = 7.7 Hz, 3H, $\mathrm{CH}_{3}$ ). ${ }^{13} \mathrm{C}\left\{{ }^{1} \mathrm{H}\right\}$ NMR $\left(125.67 \mathrm{MHz}, \delta, \mathrm{CDCl}_{3}\right): 164.4$ (s, CO) $162.7\left(\mathrm{dd},{ }^{1} \mathrm{~J}_{\mathrm{C}-\mathrm{F}}=249.6 \mathrm{~Hz},{ }^{3} \mathrm{~J}_{\mathrm{C}-\mathrm{F}}=11 \mathrm{~Hz}, \mathrm{C}^{3}, \mathrm{C}^{5}\right), 133.7(\mathrm{t}$ $\left.{ }^{3} \mathrm{~J}_{\mathrm{C}-\mathrm{F}}=9 \mathrm{~Hz}, \mathrm{C}^{1}\right), 112.4\left(\mathrm{~m}, \mathrm{C}^{2}, \mathrm{C}^{6}\right), 108.0\left(\mathrm{~m}, \mathrm{C}^{4}\right), 61.7(\mathrm{~s}$ $\left.\mathrm{CH}_{2}\right), 14.2\left(\mathrm{~s}, \mathrm{CH}_{3}\right) .{ }^{19} \mathrm{~F} \mathrm{NMR}\left(470.17 \mathrm{MHz}, \delta, \mathrm{CDCl}_{3}\right):-109.05\left(\mathrm{~m}, 2 \mathrm{~F}, \mathrm{~F}^{3}\right.$ $F^{5}$ ). MS (El, 70 eV): m/z (\%) 187 (12) [M+], 159 (54), 142 (100), 114 (54).

\section{Deuteration of 3,5-difluoroanisole}

Cesium carbonate $(11.2 \mathrm{mg}, 0.034 \mathrm{mmol})$ was introduced in a Schlenk flask with a screw cap in a nitrogen atmosphere. Then, DMSO-d6 (0.4 $\mathrm{mL}, 5.44 \mathrm{mmol})$ and 3,5-difluoroanisole $(0.04 \mathrm{~mL}, 0.34 \mathrm{mmol})$ were added. The mixture was kept in a pre-heated bath at $90^{\circ} \mathrm{C}$ during $3 \mathrm{~h}$. After that time, a mixture of isomers was observed by ${ }^{19} \mathrm{~F} \mathrm{NMR}$, being the monodeutrated compound the major one $(76 \%)$. This mixture was purified by column chromatography in silica using hexane:AcOEt (20:1) as mobile phase. Yield: $35 \mathrm{mg}(72 \%)$. Ratio protio:monoD:diD:triD = 9:76:14:1 The major product (monoD) was completely characterized.
monoD: ${ }^{1} \mathrm{H}$ NMR (499.73 MHz, $\left.\delta, \mathrm{CDCl}_{3}\right): 6.42\left(\mathrm{~m}, 2 \mathrm{H}, \mathrm{H}^{2}\right.$ $\left.\mathrm{H}^{6}\right), 3.68(\mathrm{~s}, 3 \mathrm{H}, \mathrm{OMe}) .{ }^{13} \mathrm{C}\left\{{ }^{1} \mathrm{H}\right\}$ NMR $(125.67 \mathrm{MHz}, \delta$, $\mathrm{CDCl}_{3}$ ): $163.6\left(\mathrm{dd},{ }^{1} \mathrm{~J}_{\mathrm{C}-\mathrm{F}}=249.6 \mathrm{~Hz},{ }^{3} \mathrm{~J}_{\mathrm{C}-\mathrm{F}}=17 \mathrm{~Hz}, \mathrm{C}^{3}, \mathrm{C}^{5}\right)$, $161.5\left(\mathrm{t},{ }^{3} \mathrm{~J}_{\mathrm{C}-\mathrm{F}}=14 \mathrm{~Hz}, \mathrm{C}^{1}\right), 97.8\left(\mathrm{~m}, \mathrm{C}^{2}, \mathrm{C}^{6}\right), 96.2\left(\mathrm{~m}, \mathrm{C}^{4}\right)$, 55.8 (s, OMe). ${ }^{19} \mathrm{~F} \mathrm{NMR}\left(470.17 \mathrm{MHz}, \delta, \mathrm{CDCl}_{3}\right)$ : $109.75\left(\mathrm{~m}, 2 \mathrm{~F}, \mathrm{~F}^{3}, \mathrm{~F}^{5}\right)$. MS (El, $\left.70 \mathrm{eV}\right): \mathrm{m} / \mathrm{z}(\%) 145(94)[\mathrm{M}+], 115(100)$ 102 (48).<smiles></smiles>

diD: ${ }^{19} \mathrm{~F}$ NMR $\left(470.17 \mathrm{MHz}, \delta, \mathrm{CDCl}_{3}\right):-109.8\left(\mathrm{dd},{ }^{3} \mathrm{~J}_{\mathrm{F}-\mathrm{H}}=\right.$ $\left.10 \mathrm{~Hz},{ }^{4} \mathrm{~J}_{\mathrm{F}-\mathrm{F}}=6.5 \mathrm{~Hz}, 1 \mathrm{~F}, \mathrm{~F}^{5}\right),-110.04\left(\mathrm{~d},{ }^{4} \mathrm{~J}_{\mathrm{F}-\mathrm{F}}=6.5 \mathrm{~Hz}, 1 \mathrm{~F}\right.$ $F^{3}$ ).

triD: ${ }^{19} \mathrm{~F}$ NMR $\left(470.17 \mathrm{MHz}, \delta, \mathrm{CDCl}_{3}\right):-110.08\left(\mathrm{~s}, \mathrm{~F}^{3}, \mathrm{~F}^{5}\right)$.

\section{Deuteration of other arenes: tiophene and furane.}

Potassium phosphate $(0.53 \mathrm{~g}, 2.5 \mathrm{mmol})$ or sodium hydroxide $(0.1 \mathrm{~g}, 2.5$ $\mathrm{mmol}$ ) was introduced in Schlenk flak with a screw cap in a nitrogen atmosphere (potassium phosphate for the deuteration of tiophene and sodium hydroxide for the deuteration of furane). Then, DMSO-d6 (5.6 mL, $80 \mathrm{mmol})$ and the corresponding arene $(5 \mathrm{mmol})$ were added. The mixture was kept in a pre-heated bath at $130^{\circ} \mathrm{C}$ during $24 \mathrm{~h}$. After that time, total conversion was observed, as checked by ${ }^{1} \mathrm{H}$ NMR of the crude mixture. The deuterated products were purified by distillation under vacuum, collecting the product by freezing in liquid nitrogen. All products were obtained as colorless liquids and with good yields (see Table 2).

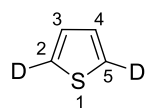

${ }^{1} \mathrm{H}$ NMR (499.73 MHz, $\left.\delta, \mathrm{CDCl}_{3}\right): 7.16\left(\mathrm{~s}, 2 \mathrm{H}, \mathrm{H}^{3}, \mathrm{H}^{4}\right)$. ${ }^{13} \mathrm{C}\left\{{ }^{1} \mathrm{H}\right\}$ NMR $\left(125.67 \mathrm{MHz}, \delta, \mathrm{CDCl}_{3}\right): 126.7\left(\mathrm{C}^{3}, \mathrm{C}^{4}\right)$, $124.9\left(1: 1: 1, \mathrm{t},{ }^{1} \mathrm{~J}_{\mathrm{C}-\mathrm{D}}=27.6 \mathrm{~Hz}, \mathrm{C}^{2}, \mathrm{C}^{5}\right) . \mathrm{MS}(\mathrm{El}, 70 \mathrm{eV})$ : $\mathrm{m} / \mathrm{z}(\%) 86(100)\left[\mathrm{M}^{+}\right], 59(45)$.

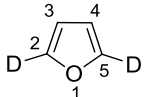

${ }^{1} \mathrm{H}$ NMR (499.73 MHz, $\left.\delta, \mathrm{CDCl}_{3}\right): 6.40\left(\mathrm{~s}, 2 \mathrm{H}, \mathrm{H}^{3}, \mathrm{H}^{4}\right)$. ${ }^{13} \mathrm{C}\left\{{ }^{1} \mathrm{H}\right\} \operatorname{NMR}\left(125.67 \mathrm{MHz}, \delta, \mathrm{CDCl}_{3}\right): 142.2\left(1: 1: 1, \mathrm{t},{ }^{1} \mathrm{~J}_{\mathrm{C}}\right.$ $\left.\mathrm{D}=30.1 \mathrm{~Hz}, \mathrm{C}^{2}, \mathrm{C}^{5}\right), 109.2\left(\mathrm{C}^{3}, \mathrm{C}^{4}\right) . \mathrm{MS}(\mathrm{El}, 70 \mathrm{eV}): \mathrm{m} / \mathrm{z}$ (\%) $70(100)\left[\mathrm{M}^{+}\right]$.

\section{Computational details}

DFT methods were used to evaluate the acidity of the (fluoro)arenes. The DFT studies have been performed with the M06 functional, ${ }^{[27,28]}$ as implemented in the Gaussian09 program package. ${ }^{[29]}$ The $6-31+G(d)$ basis set was used for $\mathrm{C}, \mathrm{O}, \mathrm{S}, \mathrm{F}$ and $\mathrm{H},{ }^{[30,31]}$ (Basis set I). Solvents effects have been considered trough the continuum model SMD for the experimental solvent, acetone $\left(\varepsilon=20.49\right.$ at $\left.25^{\circ} \mathrm{C}\right)$ or DMSO $(\varepsilon=46.83$ at $25^{\circ} \mathrm{C}$ ) in all the optimizations, frequency calculations and potential energy refinement. All structure optimizations were carried out in solvent phase with no symmetry restrictions. Free energy corrections were calculated at $363.15 \mathrm{~K}$ (the experimental temperature in most of the cases) and $10^{5} \mathrm{~Pa}$ pressure. Final potential energies were refined by performing additional single-point energy calculations; C, O, S, F and $\mathrm{H}$ were treated with $6-311++G(d, p)$ basis set (Basis set II). The calculated energies correspond to free energies in solution, obtained from potential energies with basis set II plus Gibbs energy corrections with basis set I, and are given in $\mathrm{kcal} \mathrm{mol}^{-1}$. Once calculated the Gibbs energies for the deprotonation reactions for the (fluoro)arenes, the $\mathrm{pK}_{\mathrm{a}}$ values were calculated according to the following equation: $p K_{a}=-\log \left(e^{\left(-\Delta^{G r / R T}\right)}\right)$, where: $\mathrm{R}=$ ideal gas constant; $\mathrm{T}=363.15 \mathrm{~K}$.

\section{Acknowledgements}

We thank the financial support of the Spanish MINECO (SGPI, grant CTQ2016-80913-P), the Junta de Castilla y León (grant VA062G18) and the UVa (fellowship to VS).

Keywords: Deuteration $\cdot \mathrm{H} / \mathrm{D}$ exchange $\bullet$ isotope labeling $\bullet$ fluoroarene $\cdot \mathrm{C}-\mathrm{H}$ activation

[1] a) J. Atzrodt, V. Derdau, T. Fey and J. Zimmermann, Angew. Chem Int. Ed., 2007, 46, 7744-7765; b) J. Atzrodt, V. Derdau, W. J. Kerr and M. Reid, Angew. Chem. Int. Ed. 2018, 57, 1758-1784; c) J. Atzrodt, V. Derdau, W. J. Kerr and M. Reid, Angew. Chem. Int. Ed. 2018, 57, 3022-3047.

[2] M. Gómez-Gallego and M. A. Sierra, Chem. Rev., 2011, 111, 48574863.

[3] J. Clayden, J. H. Pink, N. Westlund and F. X. Wilson, Tetrahedron Lett. 1998, 39, 8377-8380.

[4] M. Miyashita, M. Sasaki, I. Hattori, M. Sakai and K. Tanino, Science, 2004, 305, 495-499

[5] a) F. Maltais, M. Y. Jung, M. Chen, J. Tanoury, R. B. Perni, N. Mani, L. Laitinen, H. Huang, S. Liao, H. Gao, H. Tsao, E. Block, C. Ma, R. S. Shawgo, C. Town, C. L. Brummel, D. Howe, S. Pazhanisamy, S. Raybuck, M. Namchuk and Y. L. Bennani, J. Med. Chem. 2009, 52, 7993-8001; b) N. Meanwell, J. Med. Chem. 2011, 54, 2529-2591; c) E. M. Russak and E. M. Bednarczyk, Ann. Pharmacother. 2019, 53, 211 216.

[6] a) M. Simonetti, G. J. P. Perry, X. C. Cambeiro, F. Juliá-Hernández, J. N. Arokianathar and I. Larrosa, J. Am. Chem. Soc. 2016, 138, 35963606; b) Y. -B. Yu, Z. -J. Luo and X. Zhang, Org. Lett. 2016, 18, 3302-3305

[7] a) P. L. Coe, A. J. Waring and T. D. Yarwood, J. Chem. Soc. Perkin Trans. I, 1995, 2729-2737; b) M. Schlosser, L. Guio and F. Leroux, J. Am. Chem. Soc. 2001, 123, 3822-3823.

[8] P. J. Milner, T. Kinzel, Y. Zhang and S. L. Buchwald, J. Am. Chem. Soc. 2014, 136, 15757-15766.

[9] a) R. McLellan, M. Uzelac, A. R. Kennedy, E. Hevia and R. E. Mulvey, Angew. Chem. Int. Ed. 2017, 56, 9566-9570; b) L. C. H. Maddock, T. Nixon, A. R. Kennedy, M. R. Probert, W. Clegg and E. Hevia, Angew. Chem. Int. Ed. 2018, 57, 187-191.

[10] J. Lozada, Z. Liu and D. M. Perrin, J. Org. Chem. 2014, 79, 5365-5368.

[11] L. T. Ball, G. C. Lloyd-Jones and C. A. Russell, J. Am. Chem. Soc. 2014, 136, 254-264

[12] D. Whitaker, J. Burés and I. Larrosa, J. Am. Chem. Soc. 2016, 138, 8384-8387.

[13] M. D. Lotz, N. M. Camasso, A. J. Canty and M. S. Sanford, Organometallics, 2017, 36, 165-171. 
[14] C. Liu, Z. Chen, C. Su, X. Zhao, Q. Gao, G. -H. Ning, H. Zhu, W. Tang, K. Leng, W. Fu, B. Tian, X. Peng, J. Li, Q. -H. Xu, W. Zhou and K. P. Loh, Nat. Commun. 2018, 9, 80.

[15] R. P. Yu, D. Hesk, N. Rivera, I. Pelczer, P. J. Chirik, Nature, 2016, 529, 195-199.

[16] a) W. Fruhstorfer and B. Hampel, Pat. No. DE1171422, 1962; b) P. J. Paulsen and W. D. Cooke, Anal. Chem. 1963, 35, 1560.

[17] V. Salamanca, A. Toledo, A. C. Albéniz. J. Am. Chem. Soc. 2018, 140, 17851-17856.

[18] The deprotonation of the deuterated solvent by the carbonate first is also plausible. This scenario could be represented by just a vertical flip of the arrows in Scheme 2 and a switch of the positions of $\mathrm{C}_{6} \mathrm{~F}_{5} \mathrm{H}$ and $\mathrm{C}_{6} \mathrm{~F}_{5} \mathrm{D}$.

[19] J. Zheng and B. Breit, Org. Lett. 2018, 20, 1866-1870.

[20] Y. -B. Yu, S. Fan and X. Zhang, Chem. Eur. J., 2012, 18, 14643-14648.

[21] V. V. Grushin and W. J. Marshall, Organometallics, 2008, 27, 48254828.

[22] a) Y. Hu, L. Liang, W.-T. Wie, X. Sun, X.-J. Zhang and M. Yan, Tetrahedron, 2015, 71, 1425-1430; b) D. Wang, S. Chen, J. Wang, D. Astruc and B. Chen, Tetrahedron, 2016, 72, 6375-6379; c) M. Patel, R. K. Saunthwal and A. K. Verma, ACS Omega, 2018, 3, 10612-10623; d) T. R. Puleo, A. J. Strong and J. S. Bandar, J. Am. Chem. Soc. 2019, 141, 1467-1472.

[23] a) A. Streitwieser, P. J. Scannon and H. M. Niemeyer, J. Am. Chem. Soc. 1972, 94, 7936-7937; b) M. Stratakis, P. G. Wang and A Steitwieser, J. Org. Chem. 1996, 61, 3145-3150; c) Y. Fu, K. Shen, L. Liu and Q. -X. Guo, J. Am. Chem. Soc. 2007, 129, 13510-13519.

[24] A. Bagno and G. Scorrano, J. Am. Chem. Soc. 1988, 110, 4577-4582.

[25] a) F. G. Bordwell, Acc. Chem. Res. 1988, 21, 456-463; b) A. Kütt, S. Selberg, I. Kaljurand, S. Tshepelevitsh, A. Heering, A. Darnell, K. Kaupmees, M. Piirsalu and I. Leito, Tetrahedron Lett. 2018, 59, 37383748.

[26] C. -T. Yang, Y. Fu, Y. -B. Huang, J. Yi, Q. -X. Guo, L. Liu, Angew. Chem. Int. Ed. 2009, 48, 7398-7401

[27] Y. Zhao, D. G. Thuhlar, J. Chem. Phys. 2006, 125, 194101-194118.

[28] Y. Zhao, D. G. Thuhlar, Theor. Chem. Acc. 2006, 120, 215-241.

[29] Gaussian 09, Revision D.01, M. J. Frisch, G. W. Trucks, H. B. Schlegel, G. E. Scuseria, M. A. Robb, J. R. Cheeseman, G. Scalmani, V. Barone, B. Mennucci, G. A. Petersson, H. Nakatsuji, M. Caricato, X. Li, H. P. Hratchian, A. F. Izmaylov, J. Bloino, G. Zheng, J. L. Sonnenberg, M. Hada, M. Ehara, K. Toyota, R. Fukuda, J. Hasegawa, M. Ishida, T. Nakajima, Y. Honda, O. Kitao, H. Nakai, T. Vreven, J. A. Montgomery, J. E. Peralta, F. Ogliaro, M. Bearpark, J. J. Heyd, E. Brothers, K. N. Kudin, V. N. Staroverov, R. Kobayashi, J. Normand, K. Raghavachari, A. Rendell, J. C. Burant, S. S. Iyengar, J. Tomasi, M. Cossi, N. Rega, J. M. Millam, M. Klene, J. E. Knox, J. B. Cross, V. Bakken, C. Adamo, J. Jaramillo, R. Gomperts, R. E. Stratmann, O. Yazyev, A. J. Austin, R. Cammi, C. Pomelli, J. W. Ochterski, R. L. Martin, K. Morokuma, V. G. Zakrzewski, G. A. Voth, P. Salvador, J. J. Dannenberg, S. Dapprich, A. D. Daniels, Ö. Farkas, J. B. Foresman, J. V. Ortiz, J. Cioslowski, D. J Fox, Gaussian, Inc., Wallingford CT, 2009.

[30] M. M. Francl, W. J. Petro, W. J. Hehre, J. S. Binkley, M. S. Gordon, D. J. DeFrees, J. A. Pople, J. Chem. Phys. 1982, 77, 3654-3665.

[31] T. Clark, J. Chandrasekhar, P. V. R. Schleyer, J. Comput. Chem. 1983, 4, 294-301. 


\section{Entry for the Table of Contents}

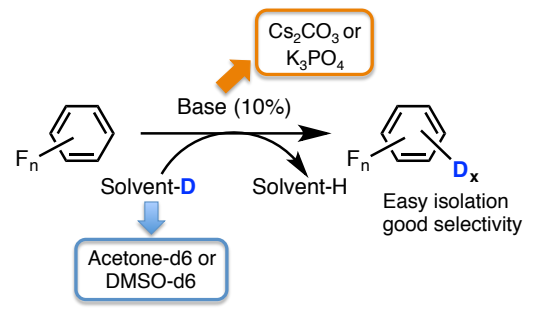

Easy deuteration of fluoroarenes with good selectivity can be achieved by H/D exchange with inexpensive deuterated solvents in a sustainable way. Just alkali metal bases are enough to bring about the exchange, which does not require a transition metal. This exchange should be taken into account when using deuterium labeling for mechanistic studies under close related conditions. 